\title{
The German State and The New Right. An Account of a Contentious Issue in The German Political Public
}

\author{
Alman Devleti ve Yeni Săg. \\ Alman Siyasal Alanında Tartışmalı Bir Konunun İncelenmesi
}

Markus J. T. SCHRIJER *

\begin{abstract}
This article examines the relation between state institutions and new right-wing movements in Germany. Using a narrative theory approach, it discusses the public communication of the state (Ministry of Defence, Ministry of the Interior and Verfassungsschutz) concerning the rise of the New Right (AfD, Identitarian Movement, Reichsbürger) in front of and via the press, primarily at the Federal Press Conference. The ambivalent positioning of the state institutions towards these challenging voices is shown: on the one hand there seems a leaning towards and, partly, shared views, and, on the other, there is sharp differentiation and even their expressed exclusion from society as a whole. The public record presented in this article reinforces the argument that the state's position towards those movements encourages and indirectly validates the New Right positions.
\end{abstract}

Keywords: Federal Republic of Germany; New Right; Federal Press Conference; Populism; Representation of the People

$\ddot{O}_{z}$ : Çalışma, Almanya'daki yeni sağ hareketler ile devlet kurumları arasındaki ilişkiyi incelemektedir. Çalışmada, anlatı kuramı yaklaşımı kullanılarak, yeni sağ (AfD, Kimlikçi Hareketi, İmparatorluk Vatandaşları) ile devlet (Savunma Bakanlığı, İç İşleri Bakanlığı ve Federal İstihbarat Teşkilâtı) arasındaki, yeni sağın yükselişi üzerine, basın ve yayın organları önünde ve onlar aracılığıyla -özellikle de Federal Basın Birliği- gerçekleşen halkla iletişim incelenmiştir. Çalışma, devlete meydan okuyan bu hareketlere karşı devletin çelişkili tutumunu ortaya koymayı amaçlamaktadır. Devlet, kimi zaman bu aşırı sağ hareketleri destekleyici nitelikte faaliyetler ve açıklamalarda bulunmakta; kimi zaman ise aşırı sağ hareketlere keskin bir biçimde karşı durmakta, hatta onların toplumun bir parçası olmadığını belirtmektedir. $\mathrm{Bu}$ çalışmada sunulan kamusal kayıtlar, devletin tutumunun, yeni aşırı sağ hareketleri cesaretlendirdiği ve dolaylı olarak Yeni Sağ'ın tutumunu geçerli kıldığı savını desteklemektedir.

Anahtar sözcükler: Federal Almanya Cumhuriyeti; Yeni Sağ; Federal Basın Konferansı; Popülizm, Kalkın Temsili

\section{The New Right and Narratives from the Federal Press Conference}

A development that has received outstanding attention in the German public over the past 10 years is the rise of new right-wing movements, especially the success of the Alternative für Deutschland party (hereinafter AfD - literally translates to 'Alternative for Germany') in both

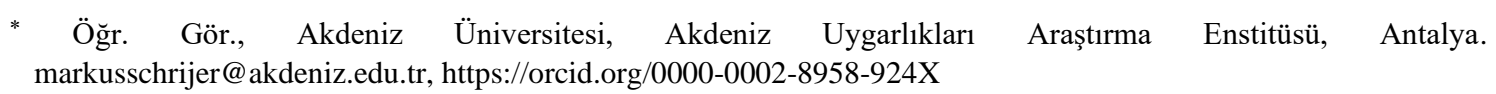


local and nationwide elections, but also that of other movements such as the Reichsbürger (literally translates to 'Citizens of the Empire') and the Identitäre Bewegung Deutschland (hereinafter IBD - literally translates to 'Identitarian Movement of Germany'. All German sources have been translated into English by the author). The term, right-wing extremism, is understood here as an ideology that is "governed by the idea that belonging to a specific ethnic group, nation, or race determines a human being's value"; and, accordingly the Volksgemeinschaft (people's community), instead of a general concept of human dignity, is seen as the basic foundation of a state and its politics (Bundesamt für Verfassungsschutz 2020). Right-wing populism is understood slightly different, as the claim to exclusively represent the (»real«) people (Müller 2016). After several years in which the challenged established political apparatus sharply distinguished itself from the challenging new voices, the question arises as to if these new right-wing movements thrive, not despite those sharp differentiations but rather due to them.

Naturally, studies on new right-wing movements focus on their leaders, programmes, supporters, strategies and so forth. For a comprehensive study in that regard, and considering Germany, see Weiß 2017. Furthermore, there is a tendency to define transnational features that would globally connect right-wing populist and extremist movements. But also reports like the one of Hedayah and SETA on the rise of Violent Radicalisation and Far-Right Extremism in Europe, which sets out to identify common features, acknowledge "that the localised context is important when determining a potential profile" (Kallis et al. 2018, 15). In agreement with that, the present understanding is that while there may be common causes like far reaching cultural and economic consequences of globalisation (or rather their reading by those movements, further see Rydgren 2018), results in individual environments will still vary (see Rovira Kaltwasser et al. 2017, for the alternative pleading to overcome a supposed fragmentation of research on populism caused by a regionally specific focus).

In Germany, major factors for the rise of right-wing populism are commonly grouped into five: sociographical consequences of unification (i.e. Kowalczuk 2019, 215ff), cultural and economic consequences of globalisation (i.e. Ther 2019, 40; Leggewie 2003, 33), social unrest due to unemployment and poverty (i.e. Butterwegge 2009, 56), racist attitudes of antisemitism and islamophobia (i.e., but stressing the differences in both, Botsch et al. 2012, 2; focusing upon Islamophobia, Younes 2018, 250) and the role of social media (Rieger 2019). These approaches, too, usually share a focus on the movements themselves - be it the impact of those factors on them, or their reaction to them. Without denying the necessity to do so, the present article instead focuses upon factors other than these, that is, primarily the reaction (and therefore, impact upon their rise) of those who are addressed by the right-wing movements. The AfD does occasionally have its say in Chapter II, as it publicly represents the contested borderline between traditional conservatives and the New Right. Jan-Werner Müller's findings may serve as a model according to which, whether intentional or not, the main incentives in the successes of right-wing populism in Germany lie with the conservative parties of the CDU and CSU that curry favour with those movements (Müller 2019). With this in mind, the first question will be if and how the public communication of German state institutions concerning the rise of rightwing movements, after 2015 (for the divide became ever greater due to the interpretations of the so-called refugee crisis) and, regardless of whether intentional or not, contributes to this rise.

The methodological approach employed is based on the theory of narrative as formulated by Albrecht Koschorke. For a sceptical view on the role of narratives in the rise the New Right, see Hermann 2019. Hermann does, however, think of narrative as "a symbolic form," which "stresses coherence, causality, and teleological drive" (Hermann 2019, 289). As will be shown below, Koschorkes approach uses a different concept, assuming a circular structure of constant 
creation and dissolution of meaning through narratives. Koschorkes interpretation is marked by his combination of the theory of narrative with the theory of culture. He refers to Jurij Lotman's model of the semiosphere (1984), in which culture does not represent "an integral, selfcontained whole of meaning, but a paradoxical structure kept alive through disintegration" (Koschorke 2012, III.2). This model does not refer to an ethnically defined group but provides a tool to describe any community of shared meaning. It is conceived of as a space in which centre and periphery are dependent on one another and, above all, the transformation of the entire structure is initiated from the periphery. This process is set and kept in motion by communication. To be able to measure change in a community, as in any such semiotic order, its communicative infrastructures and the exchange between the consolidating centre and the liquefying periphery must be analysed (Koschorke 2012, III.2). Koschorke furthermore adopts the semiotic perspective on narration as an intervention in the world and assumes a circular structure of designating (fiction) and the designated (fact), between signifier and signified, thus, a mutual constitution of language and social reality. In other words: the lingual representation of a fact retroacts on it or even precedes it. Narrating does not run alongside the real world and it not only comments on it but is itself a determining element of social practice and therefore, a tool of incessant cultural self-transformation (Koschorke 2012, I.4).

The term 'political establishment' is extremely vague. For now, it will be used as an operational term and refers, within the scope of this article, specifically to two departments of the government, namely the Ministry of Defence (hereinafter BMVg, abbreviation of Bundesministerium der Verteidigung) and Ministry of the Interior, Building and Community (hereinafter BMI, abbreviation of Bundesministerium des Innern, für Bau und Heimat) and to the Federal Office of Verfassungsschutz (hereinafter BfV, abbreviaton of Bundesamt für Verfassungsschutz, the domestic intelligence service; its name literally translates to 'protection of the constitution'). Thus, the individual movements will be presented from the perspective of that particular establishment. (It is important to keep in mind that the big coalition of CDU/CSU and SPD in the elections in 2017 lost about 14\% compared to its results in 2013. Due to the rise of AfD, there were unclear coalescing options, and it took almost half a year until a renewed big coalition was agreed upon in February 2018. The Ministries of Defence and of the Interior as well as the Federal Office of Verfassungsschutz have meanwhile always been in the hands of CDU/CSU) As will be seen, this establishment, albeit interdepending is itself not necessarily identical with the centre of the community's semiosphere. In Germany, the establishment does generally still support the semiotic centre, which rotates about the First Article of the constitution and declares a general notion of human dignity (and not any specifically defined people) as the foundation of the polity. Simultaneously, its periphery does not necessarily turn into a challenger of the political establishment. In the present case, however, it also does. The criterion for the selection of the right-wing movements is the respective relation to the Federal Republic of Germany (FRG). AfD is critical of the supposed establishment but aims at replacing it according to their views from within the parliamentary system. IBD aims at restoring the establishment and political order according to their views through extra-parliamentary opposition, without however, questioning the legitimacy of the FRG per se. The Reichsbürger ultimately aim at restoring the political order in Germany by completely denying the FRG's legitimacy and calling for the re-establishment of the German Reich. They have emerged already in the 1980s, they grew in numbers, however, and received noticeably greater public attention since around 2010 and therefore, can also be counted among the blurry term "New" Right in the scope of this article. The term of the New Right in Germany was originally coined by Claus Leggewie in 1989 to describe political movements that officially distanced themselves from the ideology of the Third Reich. In this spirit, too, many Reichsbürger would deny 
ideological proximity with National Socialism and they claim to carry on the strue « legacy of the German Reich (further see Stöss 2016). With this in mind, the article's second question enquires into the possible consequences of the interactions between semiotic periphery and centre, and interdepending, political outsiders and establishment.

When looking at narratives, it is of course important to consider their institutional setting: who is speaking, from which place, under which normative conditions, in which position and in which framework (Koschorke 2012, V.5)? The main source for this article is the Federal Press Conference (hereinafter BPK, abbreviation of Bundespressekonferenz), which shows particularly suitable for the analysis of how the political establishment in Germany deals with new forms of right-wing movements. In the Frankfurter Rundschau, the conference was described as a "game of questions and answers" (Schmale 2014). With this characterisation as a game, a central facet of the event comes to light: the meeting of media and politics as theatre, as a prelude to the debates that predominate in the country. This, however, does not suggest denying the seriousness of the actors. On the contrary, the dialogue between the governing and the governed as in a burning glass is clearly expressed here. On the part of the government, there is a state-owned claim to announce the 'official version' of an event or development - or to put it differently: to officially establish the facts; while on the part of the governed, there is the journalistic claim as the fourth estate to review this official release. (A further discussion about who or what makes up the political establishment in the FRG, the extent to which the media themselves are part of it, etc. will not be addressed here. Besides, these claims do not clearly determine an affiliation with establishment/outsiders or centre/periphery). A further peculiarity of the BPK is that the choice of respondents as well as the topics that are to be covered and the questions that are to be asked and answered shall not be selected by the government, but by the journalists themselves. Thus, Holger Schmale in the Frankfurter Rundschau, too, concludes that "this type of communication between the media and the government is a core element of the democratic public sphere in the Federal Republic" (Schmale 2014).

\section{AfD and IBD. Challengers of the Republican Identity}

At the same time as AfD was gaining strength, the new right-wing group IBD appeared, which radically rejects the political establishment using the populist narrative of a 'corrupt elite' and claims instead to really represent the Republic's principles and ideals. Firstly, the literal meaning of the word identitarian. Frauke Rüdebusch of the Society for the German Language, notes that the adjective "has so far not been found in any dictionary" and asks, "what this word is actually supposed to mean" (Rüdebusch 2019). After finding the basis in identity as 'congruence' and 'equalisation' and assigning the function of forming relative adjectives to the suffix, Rüdebusch finds as the literal meaning: ">regarding identity, belonging to being yourself and no one else, and regarding the relation to what you are" (Rüdebusch 2019). The suffix, however, can also be used to describe a person and therefore, in a figurative sense, "identitarians can be interpreted as people who live in complete congruency with what they are" (Rüdebusch 2019). What are the characteristics of a political group with such a self-designation? In the annual BfV-report of 2016, the IBD is presented as opposing the political constitution of the FRG "as an extra-parliamentary opposition" that "refuses to cooperate with political parties and institutions because it blames just them for the alleged undesirable developments in Germany" (Bundesamt für Verfassungsschutz 2016). According to this, the IBD stands for the populist claim that the 'political elite' is not acting in the interest of Germany and the German people it represents.

In a Small Request to the Federal Government in 2016, the Die Linke party asked about 
"findings relevant to the Verfassungsschutz" about the IBD (Bundesregierung 2016, 1). The government (a coalition of the CDU/CSU and SPD parties) then presented in its answer the IBD's self-image, according to which the IBD classified itself as the "metapolitical and activist arm of the new right" (Bundesregierung 2016, 1) and thus clearly differentiated itself from the Old Right (nationalists, racists, neo-Nazis): The IBD expressly rejects historical National Socialism, but is based "on the concept of 'ethnopluralism,' according to which, ideally, all states should be ethnically/culturally homogeneously structured. As a result, the IBD regards multicultural society, immigration, and Islam as a massive threat to a state" (Bundesregierung 2016, 2). To pursue its goals, it would follow the path of extra-parliamentary opposition. Overall, the government diagnosed a xenophobic ideology that was "based heavily on the principle of descent and differentiation from other cultures" and which had become radicalised as part of the 2015 refugee crisis; "Immigrants of Islamic faith" would be "partly portrayed as occupiers and unwilling to integrate, and their traditions and culture are only seen as a threat to the Western community of values" (Bundesregierung 2016, 2). Despite this finding, the government remarkably avoids explicitly answering the question of whether the IBD is rightwing extremist and refers to the pending report of the BfV.

It is also noteworthy that the government at the time "assumed a high double-digit to low three-digit number of members" (Bundesregierung 2016, 4). This would make the group extremely small in terms of its members, but enormously influential in terms of its publicity. According to the government, this impact came from its activist demeanour and media presence. Members and sympathisers "virtually network and mainly communicate via social networks" (Bundesregierung 2016, 4). In addition, their presence is fed by their international networking, above all with the Génération Identitaire in France and the IB in Austria. Even more remarkable is the subsequent assessment by the government on the question of whether "activists or members of right-wing extremist groups" are active in the IBD: "It can be assumed that rightwing extremists are trying to influence or purposefully undermine the IBD due to its positioning as an extra-parliamentary opposition within the right spectrum" - further contacts with rightwing organisations or individuals "could not be excluded" (Bundesregierung 2016, 5). The IBD itself was consequently not classified as right-wing extremist, but rather as a potential victim of right-wing extremist instrumentalisation, despite its classification as a xenophobic and antiIslamic group with a radicalised ideology based on the principle of descent.

At the time, the IBD had already been observed by the offices of Verfassungsschutz in eleven federal states and would only one month later (in August 2016), in the before mentioned pending report, be classified as a "suspicious case" by the federal BfV (Tagesschau 2016). Here, 'suspicious case' [org. 'Verdachtsfall'] is a technical term and refers to a status where the intelligence service is given more competences to observe the respective case. In this very report, however, there are lots of appeasing formulations such as: only "individual members of the IBD maintain contacts in the right-wing extremist scene" (Bundesamt für Verfassungsschutz $2016,64)$. As before by the government, the grouping is presented as vanishingly small in terms of its membership. A total of 24,350 people with "right-wing extremism potential" are listed for 2016, including as such for the first time, approx. 300 members of the IBD - this corresponds to just over $1 \%$ of all persons categorised as right-wing extremists (Bundesamt für Verfassungsschutz 2016, 40). In view of the low percentage, the enormous media attention and the broad impact of the group must catch one's eye. The BfV, in an almost appreciative tone, comes to the conclusion that "the IBD has developed into an activist organisation beyond the virtual space that draws attention to itself and its goals with regular, often spectacular public appearances" (Bundesamt für Verfassungsschutz 2016, 63). One cannot help but receive the hint of some sympathy with the group on the part of the BfV. Two years later, according to the 
annual BfV-report of 2018, the IBD has eventually "made the leap into the real world" and contained of 600 members, twice as many as in 2016 (Bundesamt für Verfassungsschutz 2018a, 82).

A few months later, the classification of the IBD as a right-wing extremist group was released. In that very statement, the BfV provided an astonishing amount of space to the (uncommented) views of the IBD. Several paragraphs read as follows:

The values of home, freedom and tradition play an important role in the IBD's self-image as part of a Europe-wide patriotic youth movement. The IBD pursues the goal of promoting these values through community activities and cultural and political educational offers (Bundesamt für Verfassungsschutz 2018b).

According to Koschorke, social conflicts are usually "choreographed along narrative field lines" (Koschorke 2012, I.4). Those who do not belong to the imaginary community are usually not given an opportunity to have their perspective presented. And in conflict situations "it is almost a taboo to equip the opposing position with a comprehensible self-view" (Koschorke 2012, II.7). Compared with this theoretical assumption, the readiness of the BfV to present the IBD in their own, very ordinary sounding perspective seems, again, remarkable.

This corresponds, however, with the prospect that, in fact, the positions of IBD are well received in parts of the German public and are not really considered extremist by any means. After all, the population appeared to be more and more dissatisfied with the work of the big coalition and the CDU-led government of chancellor Merkel. It can be perceived as a general atmosphere in the country, or simply be read from the results $-53 \%$ of the votes (in 2017) hardly qualifies for a big coalition. This is not only due to a historic low for the SPD but also due to the many voices critical of a supposed 'social-democratisation' of the conservative parties that call for a (again) more conservative profile for the CDU/CSU. Movements like the IBD claim to fill that gap, to properly representing conservative positions in German society. According to the IBD, the republic itself is not illegitimate, but its current political establishment, and the main goal must be, then, to push the establishment again to the positions of 'the people.' Keeping in mind that Lotman's centre marks a semiotic order and therefore, does not have to be synonymous with the centre of power within a political system (i.e. federal offices and other state institutions), it seems reasonable to suppose that those members of the $\mathrm{BfV}$ who were writing the above-mentioned report were themselves uncertain as to where to draw the line of right-wing extremism and legit conservatism. The following episode supports the assumption that this line was to be drawn to the right of Merkel-led CDU/CSU in their view.

On July 19, 2019, Chancellor Merkel personally participated in the BPK and was asked to assess the work of the former President of the BfV, Hans Georg Maaßen (CDU). After his dismissal, he was particularly noticeable due to positions close to AfD and downplaying the partially openly xenophobic climate of demonstrations in Germany. According to Merkel, however, he "maintained the nature of a civil servant, so to speak," since he always "followed the guidelines of the government and the ministers" and was eventually dismissed when "there were then conflicts" (Jung und Naiv 2019c). To what extent did he influence the assessment of the AfD as the representative of a state institution, which has to assess anti-constitutional practices, that is, among others right-wing populist and extremist endeavours of (political) movements? The journalist Repinski pointed out that "in the debate (...) about the AfD's observation by the BfV (...) the assessment and attitude of the Office has changed remarkably after Maaßen" (Jung und Naiv 2019c). That is to say that the BfV's attitude towards the AfD became more critical after Maaßen was no longer president; conversely, it meant that the BfV 
under Maaßen's leadership was not very concerned with the development of the AfD (and corresponding ideas and positions). Whereupon Merkel admitted: "If I look at the development of AfD, I would say that we now increasingly have certain points that one [not $u s !$ ] has to look more closely at". At the same time, she stressed: "I do not believe that complaints have to be made here about times in the past when Mr. Maaßen was President of the BfV" (Jung und Naiv 2019c). She did not go into more detail about the latent contradiction in her remark, but rather confined us from an increasingly worrying development of them, in order to dispel any charge of responsibility for that development from us. Whatever takes place in the context of rightwing populist and extremist groups, whether bound to state institutions or not, seems to be located in some distant sphere over there, not really accessible and certainly with no connection to the rest of $u s$ - whoever that may be. In any case, it does not seem to be far-fetched that the above-mentioned BfV-reports may well reflect their president's latent sympathy for right-wing populist positions.

If a community is understood, with Koschorke, as a semiosphere, and that is, as a politicalsemiotic space of power relations, then change within comes about due to uneven distribution of semiotic energies and (not congruent with them!) resource flows. This unevenness has a dynamic effect upon the centre, since the privilege of the centre exerts a kind of pull that accelerates the exchange with dynamic peripheral actors and ideas. The forces of codification and normalisation in the centre can be balanced or even outweighed by such eccentric opposing forces. But when (and why) the difference in influence will, as it were, overturn and force a radical change in the centre is an open question that depends upon the interplay of many historical factors. These (in the eyes of the centre) ideological radicalisations are often initiated by counter-elites who are sociographically close to the establishment and who legitimise their will to change by declaring themselves to be spokespersons for an oppressed group on the fringes of society. (Koschorke 2012, III.3.) The leaders of AfD, acting from the periphery, certainly do not come from the fringes of society. Frauke Petry, for example, had been awarded on federal level for her work as a chemist and entrepreneur. Jörg Meuthen had been Professor of Economics, and the current chairman of the AfD party, Alexander Gauland, played a leading role in CDU from the early 1970s up until 2013 when he left the party.

On September 9, 2016, the main topic on the BPK was the Berlin state election in which AfD won $14.2 \%$ of the votes but a coalition of SPD, the left and the green parties would add up to about $52 \%$ of the votes. Regarding the generally changing party landscape, then AfD chairwoman Frauke Petry found that politics as "ultimately a game of action and reaction did not start with the AfD," which had to be considered "a symptom of the failure of the established parties, because they are apparently no longer trusted to find solutions" (Jung und Naiv 2016a, min. 36:00). The strength of the AfD would not, however, only result from the weakness of the other parties, but above all from its "own personnel and ideas" and from constructive offers for solving crises including the resulting "political pressure" - "this is how democracy works" (Jung und Naiv 2016a, min. 36:20). According to Petry, citizens lacked politicians who "can convincingly convey content" and "that the AfD speaks plain text, and much more so than other parties, that will help us in the future, too" (Jung und Naiv 2016a, min. 36:30).

When asked about possible alternative coalitions and the CDU/CSU's refusal to consider a coalition with AfD, AfD's spokesman Jörg Meuthen pointed out that coalescing was subordinate and that it was more important to place AfD positions in German politics (Jung und Naiv 2016a, min. 29:00). This has so far been extremely successful from the standpoint of a "vital opposition," for "we can witness that positions we have been representing for some time, are taken over by the CDU and in part by the SPD" - although, as Meuthen highlights "this is not very credible from these parties (...), but anyhow: the AfD positions (...) are effective in 
opposition" (Jung und Naiv 2016a, min. 29:30). It is therefore not a question of government participation as soon as possible, the decisive point is "that we pervade with our positions" (Jung und Naiv 2016a, min. 29:30). So here, it can be concluded, too; it is that very role of opposition to the government, to 'the establishment,' that provides the leverage for the AfD (for support of this conclusion, see Decker 2016). If who- and whatever is perceived as the establishment borrows that reasoning and presents the New Right as fundamentally different, diametrically opposing, not with us, etc., the appeal will only become stronger with a growing number of people who are for any reason discontent with 'the establishment.' In this regard, it is not the executive that seems to set the tone in the country, but it is the voices and positions able to present themselves as really working in the interest of 'the people' that rule over what politics (the selection of dominating topics, the framings thereof, etc.) predominate within the country. Or to use Lotman's concept: those positions enter the centre.

The AfD's top candidate in Berlin, Georg Pazderski, concluded from the election results: "I think we have now arrived all over Germany" (Jung und Naiv 2016a, min. 02:35). The AfD is clearly not just a party of east Germany, it has also been shown that the AfD is "the largest democratic project in recent decades" regarding the entire republic (Jung und Naiv 2016a, min. 02:35). According to Pazderski, the main argument for this is the mobilisation of non-voters. The "political agenda" of the AfD would be, among other things, that "finally the interests of all citizens have a voice in parliament" (Jung und Naiv 2016a, min. 05:10). The spokesman, Jörg Meuthen agreed to this by detecting a "grandiose victory for democracy" in the increased turnout generated by the AfD (Jung und Naiv 2016a, min. 15:10). Again, the populist trope surfaces according to which 'the establishment' does not consider all citizens and certainly not 'the common people' but would rather serve other interests. This leaves unanswered the question as to of who is among those citizens that would now have found representation in the parliaments of the states and the Bundestag and who were supposedly left unnoticed and unrepresented before.

In his remarks about Kay Nerstheimer, who won the direct mandate for the AfD in Berlin Lichtenberg (2016), Tilo Jung claimed he was the head of the German Defence League in Berlin who aimed at building a militia. The Bremen Office of Verfassungsschutz report of 2014 described the GDL as an "anti-Islamic subcultural group," as a "right-wing extremist group," which sees itself as the "guardian of the Judeo-Christian, Greco-Roman tradition" in Germany (Senator für Inneres und Sport 2014, 35-38). Georg Pazderski commented on this as follows: In 2012, "long before the AfD was founded" (AfD was founded in 2013), Nerstheimer was an active member of the organisation, which was "only later on" observed by the Bremen Office of Verfassungsschutz (in 2013), when "the person concerned had quit long before and did not actually work for it anymore" (Jung und Naiv 2016a, min 16:35). So that would straighten it out: "we take the matter very seriously," we "have also examined the matter and we are still investigating" so that in the end we will "find a reasonable and good solution" (Jung und Naiv 2016a, min 16:45). Frauke Petry did not want to provide any information about possible party exclusion proceedings against Nerstheimer but suggested looking for former NPD members in the other parties instead (Jung und Naiv 2016a, min 17:25). What then was the 'good solution'? On October 3, 2016, the directorate of AfD Berlin decided to suspend Nerstheimer's membership, since high-ranking party officials expressed their uncomfortableness with it (McMinn 2016). In January 2020, the suspension was ratified on last appeal (Reinsch 2020). However, Nerstheimer saw AfD as his natural party choice - just as AfD supporters had no restraint in voting for him as AfD candidate. As a result, it is safe to say that there is ideational proximity between some of AfD's members and may be even more their supporters, and rightwing extremist views. Thus, it might not be crucial for their supporters what is written in the 
party's program but more important is the self-differentiation from 'the establishment' and the decidedly conservative positioning to the right of Merkel.

Given the theoretical presumptions, what can be taken from this chapter? Centre and periphery in Lotman's semiosphere are not rigid structures, but rather provide means of description of transformations of all kinds. At the peripheral border, the we-group is constantly defined anew, the community's internal organization is constantly established anew, and what is considered as not belonging and other is delimited, thus external disorganization again and again separated from us (Koschorke 2012, III.3). The government appeared somewhat hesitant early on to classify the IBD as right-wing extremist, some BfV's releases seemed to show sympathy with them, and its long-time president Maaßen openly supported AfD positions. Thus, it may very well be assumed that parts of the political establishment, just as society as a whole, do not regard right-wing populist positions as being illegitimate, but, on the contrary, rather identify with them (on the settling of right-wing narratives in German society, see Hornuff 2019). If then other parts of the establishment, which of course does not form a uniform block, more or less openly equally dismiss both, right-wing populist and extremist positions (and thus, blur the line between these two) of the imagined community, then the populist argument of »not being represented « seems confirmed and the extremist argument of a »legitimate community« is, as it were, smuggled into the realm of legitimate discourse.

\section{Reichsbürger: Protecting the German People and Defending Germany}

The official MAD report 2019 on right-wing extremism in the Bundeswehr (MAD stands for Militärischer Abschirmdienst, which is the German military intelligence service) was discussed in the BPK on February 8, 2019. On the part of the BMVg, frigate captain Christina Routsi, spokeswoman for personnel and recruiting, claimed to fundamentally agree with the concerning report but stressed the necessity to "comprehensively classify extremism in the Bundeswehr" as there would be "no place at all" for any extremism in the Bundeswehr (Jung und Naiv 2019a). Therefore, the topic would need to be tackled "from different directions". After all, it should be noted that "since the suspension of compulsory military service in 2017, the actual cases of extremism as a whole have decreased significantly" (Jung und Naiv 2019a). According to Routsi, "approx. 200 cases [have been] actually identified" as of 2009, including 170 before 2012; besides, most of these "cases" have already been released from the Bundeswehr (Jung und Naiv 2019a). In her view, the problem of right-wing extremism in the Bundeswehr has been solved and the army has thus become the one place in Germany that has been liberated from right-wing extremism.

Several obvious questions come to mind when presented with 30 right-wing extremist cases between 2012 and 2019: what are the features of such a case? What actions or expressions count - and who counts? How many such cases were recorded in German society over the same period overall, and how do these numbers compare? The journalist Jessen did raise concerns: he asked if it would not rather indicate extreme right-wing networks (not "cases") in the Bundeswehr if, i.e. a founding member of the KSK (Kommando Spezialkräfte, an elite unit within Bundeswehr) showed proximity and sympathy for the Reichsbürger (BR24 2019). Routsi, in return, stressed that there was "no evidence of a right-wing extremist network within the Bundeswehr" (Jung und Naiv 2019a). She did not want to provide any information on further questions either, noting that investigations were ongoing. This, of course, then raised the question as to how she came to her expressed conclusion in the first place.

Who are the so-called Reichsbürger? For the purposes of this article, noting one feature only is sufficient: the Reichsbürger do not think of the FRG as the legitimate German state, as the state of the German people, and consequently, the citizens of the FRG are in their (right-wing 
extremist) view not necessarily the 'legitimate' people of Germany. On January 25, 2017, apartment searches and raids occurred in the Reichsbürger's scene in Saxony. On the BPK the same day, Dr. Johannes Dimroth, spokesman of the BMI, pointed out that the measures were supervised by the Federal Prosecutor General, and therefore, he could say nothing specific about this case. However, he went into a question that assumed that the government might underestimate the danger posed by the Reichsbürger. He pointed out that the "serious threat" is well known which is why in 2016, all the BfV authorities of the states and the federal government declared the Reichsbürger an "object of observation" (Jung und Naiv 2017). Besides, the measures against the Reichbürger, according to Dr. Dimroth, must be viewed in the context of "initiatives and measures in the fight against right-wing extremism in general. (...) That is why we are all called, but also society as a whole, to take this struggle seriously and to take it on" (Jung und Naiv 2017). Similar formulations are commonly used in this context and are quite peculiar. We and the society appear separately from each other, as do society and rightwing extremism. This framing suggests that the government (BMI in this case), extremists (Reichsbürger) and society are different entities. It reveals the complete refusal to see right-wing extremist movements as a part of society, as something that is generated within society, which emerges from it and which (partly!) constitutes German society after all. This tendency to exclude right-wing extremist viewpoints from the community, and to entrust "the society" with taking action against them, is also a common narrative in sociological studies (for an example, see Bednarz \& Giesa 2015).

Narratives of violent conflicts, as Koschorke stresses, "are not simply lingual representations of something that exists outside of them" but modalities with which both those involved and outsiders make the conflict comprehensible and according to which they adjust for further actions. "The conflict models the narrative and the narrative models the conflict" (Koschorke 2012, IV.4). So, as the Reichsbürger speak from a peripheral position, it seems noteworthy that the centre of the semiosphere, represented by the BMI in this case, effectively adopts the coordinates of the front lines. As the political establishment is tackled along these lines, the response may seem comprehensible. The result is, however, the establishment of the notion that some parts of the German society may not legitimately belong to it. Thus, by adopting the right-wing extremist notion of a legitimate community (and additionally the populist notion of an elite set apart from it) and reversing it - not founding it on ethnicity, but on a political understanding of moderate vs extremist - that very notion, although not literally, but in essence enters the centre of the semiosphere, and thereby, may become distributed in various forms throughout the political establishment and society as a whole.

The situatedness of the Reichsbürger within or outside of society was already an explicit topic of the BPK a few months earlier, on October 31, 2016, when it was about the membership of professing Reichsbürger in the state and federal police, and again, in the Bundeswehr. Jens Flosdorff, head of the press and information office in the BMVg, pointed out that the upcoming MAD law will allow reviews of basic convictions of applicants. Special attention shall be paid to "whether there are connections to theories of the Reichsbürger, to what extent they are developed, and whether they question the constitution, so to speak" (Jung und Naiv 2016b). In this context, Dr. Dimroth (spokesman for the BMI) interfered and emphasized that no assumptions should be made towards a general tendency or generally prevailing ideas among the police and the Bundeswehr, but that always the individual case must be considered:

An ideological agreement with the goals of this group [= Reichsbürger] is, of course, in stark contradiction to what, in particular, is expected of police officers in terms of loyalty for their service to be necessary. In 
principle, of course, this also applies to any other official; because someone who rejects this state system per se - whether it is combative or not-(...) cannot technically serve for it, by all means. In this respect, an abstract statement must not be given (Jung und Naiv 2016b).

He also denied the question of whether systematic checks should be carried out, pointing out that "of course, an appropriate level of checking is generally complied with before every hiring" (Jung und Naiv 2016b). Again, there was no comment on the criteria for selecting those who do the checking. Moreover, again, there is the emphasis on a general approach to a very specific problem. There are as expected few left-wing or Islamist extremists in the army of Germany. So, there may well be good reason for a specific approach to identify a very concrete sort of extremism. It is apparent, not just since the NSU trials that, in Germany, there is a very specific danger of right-wing extremism aiming at the basic consent of the semiotic and political order. Rather than implicitly adopting an albeit reversed but essential version of the narrative of rightwing extremism, there should be the acknowledgement that there is right-wing extremism within the community, that is the German society. A lack thereof had the initially cited report of Hedayah and SETA conclude as their first recommendation: "As a starting point, there needs to be a recognition by all stakeholders that far-right violent extremism may be a significant threat to communities in Europe" (Kallis et. al. 2018, 14).

It is obviously not only crucial whether such a group should be considered an integral part of society from the perspective of the BMVg and the BMI, but also whether this group sees itself as part of society, which it ultimately is to defend when serving in the police and the Bundeswehr. Or to put it differently: what people do policemen and women think of when tasked with 'protecting the German people'? What Germany do soldiers of the Bundeswehr have in mind when 'defending the Federal Republic of Germany'? Those questions do not appear unnecessarily alarmist as they seem to be unsolved. Almost three years later, on February 13, 2019, the spokesman for the BMI, Sören Schmidt unsolicited presented a communication on the subject of compliance with the constitution by civil servants, "since this question is often brought up to the Ministry" (Jung und Naiv 2019b). Therefore, then Minister of the Interior, Horst Seehofer, decided "to examine again very carefully the question of membership and what obligations regarding personal political restraints come with that" (Jung und Naiv 2019b). Following this, civil servants must "commit themselves to the constitutional order through their entire conduct" and where this confession is not recognisable, "the basic duty" of civil servants is affected (Jung und Naiv 2019b). A relevant test cannot be carried out in general, but must always be based on the specific individual case, for:

\section{(...) in the interest of acceptance and legitimacy of state behaviour, all civil servants are obliged to avoid the slightest appearance of identification with ideas that are diametrically opposed to the free democratic basic order and with efforts that are committed to such ideas (Jung und Naiv 2019b).}

Then, Schmidt denied the question of whether there was a specific reason for this initiative of the Minister to clarify the matter. At least one conclusion can be drawn from it: If there are no centralised enquiries the decisions on those personnel in question will be taken by individual investigators. There seems to be a lack of strategy however, to investigate the investigators, or in other words: to test top-down. After MAD finding 30 soldiers in the Bundeswehr "with an absent loyalty to the constitution" and identifying most of them as right-wing extremists, and the BfV detecting eight cases of disciplinary punishment for Reichsbürger-supporters within the federal police, Seehofer did start an initiative called 'Central office for clearing up right-wing 
extremist activities in the public service' by the end of 2019 (ZDF 2019). Whilst this initiative was widely received as better late than never, many voices stressed the urgency to really tackle those "systemic individual cases" beyond mere symbolism (Hommerich 2019). For, from this, one certain conclusion can be drawn: the denial of right-wing extremism in core state institutions like police and army and its overall disintegration of $u s$, the society, and both at the same time, hardened the fronts and thereby, fostered the notion of a legitimate community, which is not identical with the citizens of the FRG.

\section{Conclusion}

Germany is witnessing an ongoing public struggle about the interpretative authority over legitimate conservatism, or more broadly, the ongoing battle for the centre of the German semiosphere. Core state institutions (BMVg, BMI, BfV), which do not necessarily represent that centre, are called upon to draw a line between conservative and right-wing extremist, anticonstitutional efforts. There are indications, however, that this line runs through those very institutions themselves and that formerly peripheral positions like the notion of a legitimate (people's) community move towards the centre of the semiosphere. In their releases and from incidents that have become public, the picture emerges of sporadic and loose sympathy on the one hand and expressed exclusion from society on the other. These contradictory positions within the establishment contribute to the rise of right-wing movements by effectively confirming them. This article reinforces the argument that, more than percentage numbers in elections, the crucial issue is the tendency to confirm with narratives the populist claim of a lack of »real representation « of all people, and to thereby possibly introduce, quasi subsurface but in essence, the right-wing extremist notion of a »legitimate (people's) community « to the centre of Germany's political culture.

Thus, following Koschorkes reading of Lotman's semiosphere and treating German society as a cultural community in that sense, one can plausibly assume certain changes in Germany respecting the understanding of its own community and polity. Restlessness, the contestation of the centre's meaning at the periphery, is common and ordinary, even elementary, as it both counteracts the manifestation of meaning, but simultaneously enables the centre's system of meaning and its appropriation by a larger number of people in the first place (Koschorke 2012, III.5). Naturally, change is inevitable, but the outcome, that is change in the above-mentioned sense, is by no means inevitable. This article concludes that, while specific features of rightwing populist and right-wing extremist movements must be considered when analysing their rise in Germany, from a narratological perspective it seems equally crucial to stress in that rise the role of the semiosphere's centre that those movements challenge. The centre, which, in Germany, is supposed to rotate about a general notion of human dignity as the foundation of the polity, and which it is to represent, may be undermined by those peripheral forces in case it gets (either willingly or unwillingly) involved in their own particular notions of a legitimate community. 


\section{BIBLIOGRAPHY}

Bednarz L. \& Giesa C. 2015, Gefährliche Bürger: Die Neue Rechte greift nach der Mitte. Hamburg.

Biermann K. 2014, "Bundestag akzeptiert Blogger als Reporter”. Die Zeit, 14 Mart 2014. Kaynak: https://www.zeit.de/gesellschaft/2014-03/blogger-bundestag-beckedahl-jung. Erişim Tarihi: 26 Eylül 2019.

Botsch G., O. Glöckner, C. Kopke \& M. Spieker, (Eds.) 20124, Islamophobie und Antisemitismus. Berlin.

BR24 2019, Eylül 10, Rechtsextremismus-Vorwürfe gegen Bundeswehrkommando KSK. Kaynak: https://www.br.de/nachrichten/deutschland-welt/rechtsextremismus-vorwuerfe-gegenbundeswehrkommando-ksk,Rbe2ir6. Erişim Tarihi: 16 Mayıs 2020.

Bundesamt für Verfassungsschutz 2016, "Verfassungsschutzbericht 2016“. Eds. Bundesministerium des Innern. Kaynak: https://www.verfassungsschutz.de/embed/vsbericht-2016.pdf. Erişim Tarihi: 29 Eylül 2019.

Bundesamt für Verfassungsschutz 2018a, "Verfassungsschutzbericht 2018“. Eds. Bundesministerium des Innern, für Bau und Heimat. Kaynak: https://www.verfassungsschutz.de/embed/vsbericht-2018.pdf. Erişim Tarihi: 26 Eylül 2019.

Bundesamt für Verfassungsschutz 2018b, "Identitäre Bewegung Deutschland (IBD)". Kaynak: https://www.verfassungsschutz.de/de/arbeitsfelder/af-rechtsextremismus/zahlen-und-faktenrechtsextremismus/identitaere-bewegung-deutschland-2018. Erişim Tarihi: 29 Eylül 2019.

Bundesamt für Verfassungsschutz 2020, "What is right-wing extremism?". Kaynak: https://www. verfassungsschutz.de/en/fields-of-work/right-wing-extremism/what-is-right-wing-extremism. Erişim Tarihi: 14 Mayıs 2020.

Bundespressekonferenz 2020, “Der Verein”. Kaynak: https://www.bundespressekonferenz.de/index. php?option=content\&id=60. Erişim Tarihi: 14 Mayıs 2020.

Bundesregierung 2016, Temmuz 19, “Antwort der Bundesregierung auf die Kleine Anfrage der Abgeordneten Martina Renner, Ulla Jelpke, Katrin Kunert, weiterer Abgeordneter und der Fraktion DIE LINKE. - Drucksache 18/9014 - Einschätzung und Aktivitäten der „Identitären“. “Der Deutsche Bundestag, Drucksache 18/9218. Kaynak: https://dipbt.bundestag.de/doc/btd/18/092/1809218.pdf. Erişim Tarihi: 07 Ekim 2019.

Butterwegge C. 20094, “Globalisierung als Spaltpilz und sozialer Sprengsatz”. Eds. C. Butterwegge \& G. Hentges, Zuwanderung im Zeichen der Globalisierung, Wiesbaden, 55-102.

Decker F. 2016, "The Alternative for Germany: Factors behind its emergence and profile of a new rightwing populist party". German Politics and Society 34/2, 1-16.

Die Zeit 2019, Nisan 04, "Identitären-Chef hat Job im Bundestag". Kaynak: https://www. zeit.de/politik/deutschland/2019-04/rechtsextremismus-identitaere-bewegung-afd-daniel-fissbundestag. Erişim Tarihi: 29 Eylül 2019.

Herles P. 08 Ekim 2009, "Bundespressekonferenz feiert 60. Geburtstag”. General-Anzeiger. Kaynak: https://www.general-anzeiger-bonn.de/bonn/bundespressekonferenz-feiert-60-geburtstag_aid40452211. Erişim Tarihi: 23 Eylül 2019.

Herrmann S.M. 2019, "Post-truth = Post-narrative? Reading the narrative liminality of transnational rightwing populism”. Eds. N. Morgan, A. Hornung \& T. Tatsumi, The Routledge Companion to Transnational American Studies. New York, 288-296.

Hommerich L. 18 Aralık 2019, “Einzelfälle mit System”. Die Zeit. Kaynak: https://www. zeit.de/politik/deutschland/2019-12/rechtsextremismus-horst-seehofer-afd-beamte-verfassungsschutz. Erişim Tarihi: 16 Mayıs 2020.

Hornuff S. 2019, Die Neue Rechte und ihr Design. Vom ästhetischen Angriff auf die offene Gesellschaft. Bielefeld.

Jung und Naiv 2016a, "Rückkehr der AfD in die Bundespressekonferenz (Komplett) - 19. September 2016”.Kaynak:http://www.jungundnaiv.de/2016/09/19/rueckkehr-der-afd-in-diebundespressekonferenz-komplett-19-september-2016/. Erişim Tarihi: 27 Eylül 2019.

Jung und Naiv 2016b, "Bundesregierung für Desinteressierte: BPK vom 31. Oktober 2016". Kaynak: 
http://www.jungundnaiv.de/2016/10/31/bundesregierung-fuer-desinteressierte-bpk-vom-31-oktober2016/. Erişim Tarihi: 29 Eylül 2019.

Jung und Naiv 2017, "Bundesregierung für Desinteressierte: Komplette BPK vom 25. Januar 2017". Kaynak:http://www.jungundnaiv.de/2017/01/25/bundesregierung-fuer-desinteressierte-komplettebpk-vom-25-januar-2017/. Erişim Tarihi: 30 Eylül 2019.

Jung und Naiv 2018a, "Merkel, Seehofer \& Scholz zum Koalitionsvertrag - BPK vom 12. März 2018". Kaynak: http://www.jungundnaiv.de/2018/03/14/merkel-seehofer-scholz-zum-koalitionsvertrag-bpkvom-12-maerz-2018/. Erişim Tarihi: 28 Eylül 2019.

Jung und Naiv 2018b, "BürgerPresseKonferenz mit Mitgliedern des Petitionsausschusses im Bundestag". Kaynak:http://www.jungundnaiv.de/2018/09/07/buergerpressekonferenz-mit-mitgliedern-despetitionsausschusses-im-bundestag/. Erişim Tarihi: 25 Eylül 2019.

Jung und Naiv 2019a, "Bundesregierung für Desinteressierte: BPK vom 8. Februar 2019". Kaynak: http://www.jungundnaiv.de/2019/02/08/bundesregierung-fuer-desinteressierte-bpk-vom-8-februar2019/. Erişim Tarihi: 30 Eylül 2019.

Jung und Naiv 2019b, "Bundesregierung für Desinteressierte: BPK vom 13. Februar 2019". Kaynak: http://www.jungundnaiv.de/2019/02/13/bundesregierung-fuer-desinteressierte-bpk-vom-13-februar2019/. Erişim Tarihi: 26 Eylül 2019.

Jung und Naiv 2019c, "Bundeskanzlerin für Desinteressierte: Angela Merkel in der BPK vom 19. Juli 2019”. Kaynak:http://www.jungundnaiv.de/2019/07/19/bundeskanzlerin-fuer-desinteressierte-angelamerkel-in-der-bpk-vom-19-juli-2019/. Erişim Tarihi: 25 Eylül 2019.

Kallis A., S. Zeiger \& B. Öztürk (Eds.) 2018. Violent Radicalisation \& Far-Right Extremism in Europe. Ankara.

Koschorke A. 2012², Wahrheit und Erfindung. Grundzüge einer Allgemeinen Erzähltheorie. E-Book. Frankfurt a. M. [İngilizce: Koschorke A. 2018, Fact and Fiction. Elements of a General Theory of Narrative. Çev. Joel Golb. Berlin.]

Kowalczuk I.-S. 20196, Die Übernahme. Wie Ostdeutschland Teil der Bundesrepublik wurde. München.

Leggewie C. 2003, "Rechts gegen Globalisierung”. Internationale Politik 4, 33-40.

McMinn L. 2016, Ekim 03, "Nach der Berlin-Wahl: Berliner AfD will Kay Nerstheimer ausschließen". Der Tagesspiegel. Kaynak: https://www.tagesspiegel.de/berlin/nach-der-berlin-wahl-berliner-afdwill-kay-nerstheimer-ausschliessen/14636534.html. Erişim Tarihi: 12 Mayıs 2020.

Müller J.-W. 2016, What is Populism? Philadelphia.

Müller J.-W. 2019, Haziran 11, "Was ist am Populismus so gefährlich? - Es ist die Mitte, die sich an den Rändern anbiedert”. Neue Zürcher Zeitung. Kaynak: https:/www.nzz.ch/meinung/gefaehrlich-ampopulismus-sind-seine-steigbuegelhalter-in-der-mitte-ld.1487000. Erişim Tarihi: 20 Eylül 2019.

Reinsch M. 2020, Ocak 21, "Berliner AfD schließt Kay Nerstheimer aus Partei aus”. Berliner Zeitung. Kaynak: https://www.berliner-zeitung.de/politik-gesellschaft/berliner-afd-schliesst-kay-nerstheimervon-partei-aus-li.5318. Erişim Tarihi: 14 Mayıs 2020.

Rieger D. 2019, Mayıs 09, "Diskussionsräume und Radikalisierungsprozesse in sozialen Medien". Eds. Bundeszentrale für Politische Bildung. Kaynak: https:/www.bpb.de/politik/extremismus/ rechtspopulismus/290851/diskussionsraeume-in-sozialen-medien. Erişim Tarihi: 20 Mayıs 2020.

Rovira Kaltwasser C., P. A. Taggart, E. P. Ochoa \& P. Ostiguy (Eds.) 2017, The Oxford Handbook of Populism. Oxford.

Rüdebusch F. 2019, "Identität - identisch - identitär”. Eds. Gesellschaft für Deutsche Sprache, Der Sprachdienst 2. Kaynak: https://gfds.de/identitaet-identisch-identitaer/. Erişim Tarihi: 14 Eylül 2019.

Rydgren J. (Ed.) 2018, The Oxford Handbook of the Radical Right. New York.

Schmale H. 2014, Ekim 10, "Hier haben die Journalisten das Sagen". Frankfurter Rundschau. Kaynak: https://www.fr.de/kultur/hier-haben-journalisten-sagen-11257273.html. Erişim Tarihi: 18 Eylül 2019.

Senator für Inneres und Sport 2014, "Verfassungsschutzbericht 2014”. Eds. Freie Hansestadt Bremen. Kaynak:

https://web.archive.org/web/20150613023125/https://ssl.bremen.de/verfassungsschutz/sixcms/media. 
php/13/Verf-Bericht-2014.pdf?backend_call=true. Erişim Tarihi: 02 Ekim 2019.

Stöss R. 2016, "Die "Neue Rechte" in der Bundesrepublik. "Eds. Bundeszentrale für Politische Bildung. Kaynak: https://www.bpb.de/politik/extremismus/rechtsextremismus/229981/die-neue-rechte-in-derbundesrepublik. Erişim Tarihi: 04 Eylül 2020.

Tagesschau 2016, Ağustos 12, "Bundesverfassungsschutz beobachtet »Identitäre«". ARD-Tagesschau. Kaynak:https://www.tagesschau.de/inland/rechtsextremismus-verfassungsschutz-identitaerebewegung-101.html. Erişim Tarihi: 04 Ekim 2019.

Tagesschau 2019, Temmuz 19, “»Identitäre« als rechtsextremistisch eingestuft”. ARD-Tagesschau. Kaynak: https://www.tagesschau.de/inland/identitaere-121.html. Erişim Tarihi: 13 Eylül 2019.

Ther P. 2019², Das andere Ende der Geschichte. Über die Große Transformation. Berlin.

Weiß V. 2017, Die autoritäre Revolte: Die Neue Rechte und der Untergang des Abendlandes. Stuttgart.

Younes A.-E. 2018, "Germany". Eds E. Bayraklı \& F. Hafez, European Islamophobia Report 2017. Ankara, 247-282.

ZDF 2019, Aralık 17, "Rechtsextremismus: Seehofer will Behörden prüfen". Kaynak: https://www.zdf.de/nachrichten/heute/seehofer-will-behoerden-auf-rechtsextremismus-ueberpruefen100.html. Erişim Tarihi: 17 Aralık 2019. 